\title{
The Prevalence and Outcomes of Influenza Virus Infection in Heart Failure Patients in Brazil: Influenza Infection in Heart Failure
}

\author{
Henrique Godoy ${ }^{*}$, Juliana Soares ${ }^{1}$, Paula Zanellatto Neves ${ }^{2}$, \\ Nancy Cristina Junqueira Bellei ${ }^{3}$, Dirceu R. Almeida ${ }^{1}$ \\ ${ }^{1}$ Division of Cardiology, Department of Medicine, Federal University of São Paulo, São Paulo, Brazil \\ ${ }^{2}$ Hospital Epidemiology Committee, Federal University of São Paulo, São Paulo, Brazil \\ ${ }^{3}$ Clinical Virology Laboratory, Division of Infectious Diseases, Department of Medicine, Federal University of \\ São Paulo, São Paulo, Brazil \\ Email: ${ }^{*}$ godoy.henrique@gmail.com
}

Received 16 June 2015; accepted 30 August 2015; published 2 September 2015

Copyright (C) 2015 by authors and Scientific Research Publishing Inc.

This work is licensed under the Creative Commons Attribution International License (CC BY). http://creativecommons.org/licenses/by/4.0/

c) (i) Open Access

\begin{abstract}
Background: Respiratory tract infections were associated with acute exacerbations of heart failure (HF). However, the role of the influenza virus, a major agent of such infections, in this population remained unclear. Method: During the influenza virus seasons of 2013 and 2014 we prospectively assessed influenza respiratory illnesses in a cohort of adults primarily hospitalized for management of acute decompensated HF and a cohort of HF outpatients. Qualitative RT-PCR for influenza $A(A / H 1, A / H 12009 p d m, A / H 3)$ and $B$ virus testing was performed on nasopharyngeal swab samples. Result: A total of 121 patients were included, $58.3 \%$ males $(n=70)$, mean age 57.7 years old $( \pm 14.0)$, mean left ejection fraction $35.3( \pm 9.8)$. Of these, $50.4 \%$ were inpatients $(n=61)$. The prevalence of symptoms of respiratory infections was $28.0 \%(n=34)$ and $4.9 \%(n=6)$ of all samples were positive for influenza virus. Only influenza $A$ was detected and all cases were among inpatients. Influenza-positive patients had a greater need for antimicrobials $(83.3 \%, n=5 ; 16.3 \%$, $n=9 ; p=0.001)$ and for mechanical ventilation $(50.0 \%, n=3 ; 3.6 \%, n=2 ; p<0.001)$ than Influenza-negative patients. The prevalence of influenza virus was not related to mortality (OR 4.58; $p=$ 0.16). Conclusion: Although not common, the influenza virus infection resulted in worst outcomes, with a greater need for antimicrobials and mechanical ventilation. Immunization and antiviral treatment in high risk patients may positively impact their outcomes.
\end{abstract}

\section{Keywords}

Influenza Virus, Heart Failure, Epidemiology

\footnotetext{
"Corresponding author.
}

How to cite this paper: Godoy, H., Soares, J., Neves, P.Z., Bellei, N.C.J. and Almeida, D.R. (2015) The Prevalence and Outcomes of Influenza Virus Infection in Heart Failure Patients in Brazil: Influenza Infection in Heart Failure. Advances in Infectious Diseases, 5, 95-100. http://dx.doi.org/10.4236/aid.2015.53011 


\section{Introduction}

The influenza virus is one of the most frequent agents causing respiratory infections [1]. Each year, between 5 and $20 \%$ of the world population is infected [2], with up to 200,000 hospitalizations and 36,000 deaths in the US alone [3]. While most people experience an acute, febrile, self-limited illness with mild respiratory symptoms, some groups are considered at risk of hospitalization and death, such as children, the elderly and the chronically ill [4].

Several studies suggest that viral respiratory infections lead to an exacerbation of chronic pulmonary diseases, resulting in an excess of hospitalizations and deaths [5] [6], but little is known about the impact of these infections on patients with heart failure (HF). Hospitalizations for HF increase significantly in winter, even in tropical countries like Brazil [7]-[9]. Godoy et al. [7] showed a consistent increase in the number of HF hospitalizations during the winter months over a period of 20 years. Sandoval et al., while retrospectively assessing the impact of two influenza virus seasons on the population from the Studies of Left Ventricular Dysfunction (SOLVD), found a significantly higher risk of hospitalization for HF, but no increase in mortality rates [10].

In addition, many patients with HF may be hospitalized for other causes related to influenza virus, such as bacterial pneumonia, where the viral etiology is not investigated or identified [4]. In the Organized Program to Initiate a Lifesaving Treatment in Hospitalized Patients with Heart Failure Registry (OPTIMIZE-HF) [11], respiratory infections are the precipitating factors in $15.3 \%$ of the patients hospitalized for HF. These patients also stay longer in hospital and their risk of death during hospitalization is $60.0 \%$ higher.

HF is the main cause of hospitalization among North American adults older than 65; there are over 3.6 million hospitalizations per year with high hospital mortality rates and significantly elevated costs [7] [12]-[14]. It is very important to understand which factors contribute to the exacerbation of HF, especially preventable ones, since this may favorably influence the management of HF. Despite the fact that influenza virus is a public health issue and is the only respiratory virus for which effective prophylaxis and treatment are available, no study has directly assessed the impact of influenza infection on the HF population to date.

\section{Materials and Methods}

This was a single center, prospective cohort study. Study approval was obtained from the Institutional Review Board. During the influenza virus seasons of 2013 and 2014 two different cohorts of HF patients were analyzed and compared for the prevalence of influenza virus infection: (1) inpatients sequentially hospitalized primarily for management of acute decompensated HF, and (2) outpatients from the institution's HF clinic. They were matched for sex, age and left ventricle ejection fraction. Patients aged less than 18 years old and those with congenital heart disease were excluded. The diagnosis of acute decompensated HF was made according to ACC/AHA guidelines [13]. Symptoms of respiratory tract infection within 5 days of admission (fever, sneezing, running nose, myalgia, chills, sore throat, and cough) were searched for in all patients, but they were not a mandatory requirement for inclusion. Outpatients were followed up after 30 days of study inclusion in the HF clinic or by telephone when necessary. The study investigators were not involved in the patients' clinical management.

Nasopharyngeal swab samples were collected within 24 hrs of hospital admission. A qualitative RT-PCR for influenza virus A (A/H1, A/H12009pdm, A/H3) and B was performed according to the Centers for Disease Control and Prevention protocol [14]. Blood tests were also performed for NT pro-BNP (N-terminal pro b-type natriuretic peptide), C-reactive protein, hemoglobin count, white blood count, serum creatinine, serum sodium, and left ventricular ejection fraction obtained by transthoracic echocardiography. Clinical outcomes were investigated, including in-hospital mortality rate for any reason; need for antimicrobial therapy for any reason within 72 hrs of hospitalization; intravenous inotropic drug infusion (dobutamine, milrinone, other); mechanical ventilation; and incidence of cardiorenal syndrome, defined as an increase of $0.5 \mathrm{mg} / \mathrm{dL}$ in serum creatinine levels during hospitalization. Any outpatient hospital admission within 30 days of study inclusion was also investigated.

Categorical variables are presented in percentages. Continuous variables are expressed as means \pm standard deviation (SD). Categorical variables were compared using the Fisher's exact test, and continuous variables using Student's $t$ test or the Mann Whitney $U$ test. Stepwise forward logistic regression was used for multivariate analysis. $P<0.05$ was considered statistically significant.

\section{Results}

In total, 121 patients were included, $58.3 \%$ males $(n=70)$, mean age 57.7 years old $( \pm 14.0)$, mean left ejection 
fraction $35.3( \pm 9.8)$. Of these, $50.4 \%$ were decompensated HF patients $(n=61)$. There was a $16.0 \%$ mortality rate $(n=8)$ among the decompensated HF patients and $1.6 \%$ in outpatients HF group $(n=1)$. In comparison with inpatients, more of the outpatients were immunized against influenza virus $(p=0.028)$, and were following the ACC/AHA HF guidelines' recommended therapy (Table 1).

The overall prevalence of influenza virus was $4.9 \%(n=6)$, and all infections were among decompensated patients $(9.8 \% ; n=6)$. Nevertheless the number of patients with symptoms of respiratory tract infection was similar between groups (inpatients 31.1\%, $n=19$; outpatients $25.0 \%, n=15 ; p=0.481$, respectively) (Table 1). Only influenza A was observed and all positive patients were symptomatic for respiratory tract infection.

The clinical characteristics of inpatients who were RT-PCR-positive or -negative for influenza virus were similar (Table 2), however positive patients had a greater need for antimicrobials $(83.3 \%, n=5 ; 16.3 \%, n=9 ; p=$ 0.001 , respectively) and mechanical ventilation (50.0\%, $n=3 ; 3.6 \%, n=2 ; p<0.001)$ (Table 2). The odds ratio was 4.58 for mortality from influenza virus $(p=0.16)$, and 12.6 for the use of mechanical ventilation $(p=0.05)$ (Table 3).

\section{Discussion}

The influenza virus season in Brazil usually starts in April and ends in September and is often accompanied by other respiratory viruses, particularly the respiratory syncytial virus (RSV) [15]. However, the influenza virus is the only respiratory virus for which effective prophylaxis and treatment are available. One third of patients in our sample have symptoms of respiratory tract infection, but influenza virus activity is only documented among inpatients during the two consecutive seasons. In comparison with outpatients, fewer inpatients mention regular use of ACE inhibitors and beta blockers or immunization against influenza virus. Sandoval et al. [10] found that influenza infection was responsible for $11.0 \%$ of all HF hospitalizations in the retrospective SOLVD study.

Table 1. Clinical characteristics of study population.

\begin{tabular}{|c|c|c|c|}
\hline Characteristics & Inpatients $(n=61)$ & Outpatients $(n=60)$ & $p$ \\
\hline Male (\%) & $32(52.5)$ & $38(63.3)$ & 0.318 \\
\hline Age (SD) & $57.3( \pm 14.2)$ & $56.9( \pm 13.8)$ & 0.855 \\
\hline Left ventricular ejection fraction (SD) & $36.6 \%( \pm 11.5)$ & $34.9 \%( \pm 8.7)$ & 0.393 \\
\hline Atrial fibrillation (\%) & $24(39.3)$ & 19 (31.6) & 0.309 \\
\hline Hemoglobin (g/dL) & $12.6( \pm 2.1)$ & $13.4( \pm 2.3)$ & 0.402 \\
\hline Creatinine (mg/dL) & $1.6( \pm 1.1)$ & $1.4( \pm 0.8)$ & 0.031 \\
\hline Sodium $(\mathrm{mEq} / \mathrm{L})$ & $136( \pm 4.1)$ & $138( \pm 3.1)$ & 0.608 \\
\hline White blood count $\left(/ \mathrm{mm}^{3}\right)$ & $8,889( \pm 4,620)$ & $8,577( \pm 3,085)$ & 0.006 \\
\hline C-reactive protein $(\mathrm{mg} / \mathrm{L})$ & $36.5( \pm 55.4)$ & $6.5( \pm 9.9)$ & 0.0001 \\
\hline NT pr-BNP (pg/mL) & $10,278( \pm 8,957)$ & $1,080( \pm 320)$ & 0.0001 \\
\hline Respiratory tract infections & 19 (31.1) & $15(25.0)$ & 0.418 \\
\hline RT-PCR Influenza virus (\%) & $6(9.8)$ & 0 & 0.008 \\
\hline Immunization against influenza virus (\%) & $21(34.4)$ & $33(55.0)$ & 0.028 \\
\hline Beta blockers (\%) ${ }^{1}$ & $47(77.0)$ & 58 (96.6) & 0.002 \\
\hline ACE inhibitors/ARB (\%) $)^{1}$ & $51(81.3)$ & $57(95.0)$ & 0.068 \\
\hline Aldosterone receptor antagonist (\%) $)^{1}$ & $33(54.1)$ & $42(70.0)$ & 0.090 \\
\hline Hospital admissions (\%) & - & $5(8.3)$ & - \\
\hline Deaths (\%) & $8(13.1)$ & $1(1.6)$ & 0.016 \\
\hline
\end{tabular}

SD: standard deviation; ${ }^{1}$ prior to hospital admission. 
Table 2. Clinical characteristics and outcomes in RT-PCR influenza virus positive patients.

\begin{tabular}{lccc}
\hline Variables & Influenza virus positive $(n=6)$ & Influenza virus negative $(n=55)$ & $p$ \\
\hline Male (\%) & $3(50.0)$ & $29(52.7)$ & 1.0 \\
Age (SD) & $61.6( \pm 10.8)$ & $56.9( \pm 14.6)$ & 0.662 \\
Left ventricular ejection fraction (SD) & $43.8 \%( \pm 12.3)$ & $36.1 \%( \pm 11.1)$ & 0.118 \\
Atrial fibrillation (\%) & $3(50.0)$ & $21(38.2)$ & 0.670 \\
Antimicrobial use (\%) & $5(83.3)$ & $9(16.3)$ & 0.001 \\
Inotropic drugs (\%) & $2(33.3)$ & $10(22.2)$ & 0.616 \\
Mechanical ventilation (\%) & $3(50.0)$ & $2(3.6)$ & $<0.001$ \\
Cardiorenal syndrome (\%) & $5(83.3)$ & $21(42.9)$ & $6(10.9)$ \\
Deaths (\%) & $2(33.3)$ & & 0.09 \\
\hline
\end{tabular}

SD: standard deviation.

Table 3. Multivariate analysis for mortality in the study cohort.

\begin{tabular}{lccc}
\hline & OR & CI (95.0\%) & $p$ \\
\hline Age & 1.005 & $0.86-70.32$ & 0.88 \\
Gender FEMALE & 1.716 & $1.47-31.26$ & 0.60 \\
Antimicrobial use & 2.784 & $1.47-31.26$ & 0.41 \\
Atrial fibrillation & 2.041 & $1.05-35.58$ & 0.50 \\
Cardiorenal syndrome & 1.082 & $0.52-80.11$ & 0.94 \\
Influenza virus & 4.58 & $1.05-20.45$ & 0.16 \\
Inotropic drugs & 1.924 & $2.95-32.70$ & 0.65 \\
Left ventricular ejection fraction & 53.593 & $1.05-75.83$ & 0.42 \\
Mechanical ventilation & 12.606 & $1.36-20.25$ & 0.05 \\
Respiratory tract infections & 0.424 & $0.25-12.36$ & 0.63 \\
\hline
\end{tabular}

OR: Odds Ratio.

The patients at highest risk in this study are those with symptomatic HF (NYHA > 2) and those who are not on ACE inhibitors. We thus hypothesize that the better the HF care, the lower the risk of influenza infection.

In our study, which to our knowledge is the first to prospectively investigate influenza virus in HF patients, the overall prevalence of infection is lower than expected [15] [16]. Previous surveys in the general Brazilian population demonstrated a prevalence of influenza virus of about $20.0 \%$. However the detection of virus activity in Brazil had declined since the 2009 pandemic, reflecting the lower circulation of the virus over the years and the increased prevalence of vaccination among the Brazilian population [15]-[17].

More than $70.0 \%$ of the general Brazilian population has been vaccinated over the years thanking to a successful government campaign [15]. Although patients with chronic disease may be vaccinated, the main target populations are children, pregnant women and the elderly, which may have contributed to the low rate of immunization in our population. Although different guidelines for HF management recommend immunization against influenza virus [1] [4] [14] [18], no vaccination studies have included HF patients. In coronary artery disease patients [19], one vaccination study shows a $75.0 \%$ reduction in the risk of cardiovascular death, and further $50.0 \%$ reduction in reinfarction or re-hospitalization for myocardial ischemia.

While dyspnea and respiratory failure are common findings during HF exacerbations, our data suggest more severe disease in infected patients, with a 7-fold increased risk of mechanical ventilation. In fact, the main clini- 
cal syndrome of influenza virus leading to ICU hospitalization is viral pneumonitis. During the 2009-2010 pandemic, this syndrome accounted for approximately half the ICU admissions and a higher rate of use of mechanical ventilation [20]-[23]. A highly amplified inflammatory response and direct alveolar damage have been shown to play a contributory role in the higher rate of respiratory distress and hypoxemia [24] [25].

The appropriate use of diagnostic tests, along with early administration of antiviral drugs, may improve the clinical outcomes of influenza virus infections, reducing the incidence of secondary bacterial infections and the use of antimicrobials [4]. In our study, the use of antimicrobials (appropriate or not) is 4 times more common among patients with influenza virus. In adults and adolescents with a proven influenza illness, oseltamivir treatment reduces overall antibiotic use for any reason by $26.7 \%$ and the incidence of influenza-related lower respiratory tract complication resulting in antibiotic therapy by $55.0 \%$ compares with placebo [26].

Our study has several limitations. The observational design of the study precludes determination of causality of HF hospitalization. Also, our relatively small sample size limits the statistical power to detect clinically meaningful associations or confounding factors. Due to the lack of statistical power for these subjects, these results should be interpreted with caution.

Under such conditions, we conclude that influenza virus infection was not a prevalent co-morbidity among HF patients during 2013-2014 virus seasons; however the presence of influenza virus infection may interfere unfavorably in the outcome of patients with HF exacerbations, especially by causing respiratory failure with need for mechanical ventilation. Therefore, influenza virus infection surveillance should be intensified among HF patients during the influenza season. Patients at high risk for hospitalization should be immunized, and antiviral treatment may positively impact the clinical outcome.

\section{Funding Sources}

Conselho Nacional de Desenvolvimento Científico e Tecnológico (CNPQ) and Coordenação de Aperfeiçoamento de Pessoal de Nível Superior (CAPES)-Brazilian Federal Education Department.

\section{Disclosures}

None.

\section{References}

[1] Mandell, L.A., Wunderink, R.G. and Anzueto, A. (2007) Infectious Diseases Society of America/American Thoracic Society Consensus Guidelines on the Management of Community-Acquired Pneumonia in Adults. Clinical Infectious Diseases, 44, S27-S72. http://dx.doi.org/10.1086/511159

[2] World Health Organization (2009) Fact Sheet on Influenza. www.who.int/mediacentre/factsheets/fs211/en/index.html

[3] Thompson, W.W., Shay, D.K., Weintraub, E., Brammer, L., Bridges, C.B., Cox, N.J. and Fukuda, K. (2004) InfluenzaAssociated Hospitalizations in the United States. Journal of the American Medical Association, 292, 1333-1340. http://dx.doi.org/10.1001/jama.292.11.1333

[4] Harper, S., Bradley, .J, Englund, J., File, T., Gravenstein, S., Hayden, F., McGeer, A., Neuzil, K., Pavia, A., Tapper. M., Uyeki, T., Zimmerman, R. and America, E. (2009) Seasonal Influenza in Adults and Children-Diagnosis, Treatment, Chemoprophylaxis, and Institutional Outbreak Management: Clinical Practice Guidelines of the Infectious Diseases Society of America. Clinical Infectious Diseases, 48, 1003-1032. http://dx.doi.org/10.1086/598513

[5] Wongsurakiat, P., Maranetra, K., Wasi, C., Kositanont, U., Dejsomritrutai, W. and Charoenratanakul, S. (2004) Acute Respiratory Illness in Patients with COPD and the Effectiveness of Influenza Vaccination: A Randomized Controlled Study. Chest, 125, 2011-2020. http://dx.doi.org/10.1378/chest.125.6.2011

[6] Godoy, H.L., Silveira, J., Segalla, E. and Almeida, D. (2011) Hospitalization and Mortality Rates for Heart Failure in Public Hospitals in São Paulo. Arquivos Brasileiros de Cardiologia, 97, 402-407. http://dx.doi.org/10.1590/S0066-782X2011005000096

[7] Stewart, S., McIntyre, K., Capewell, S. and McMurray, J.J. (2002) Heart Failure and Cold Climate. Seasonal Variation in Heart Failure Related Mortality. Journal of the American College of Cardiology, 39, 760-766. http://dx.doi.org/10.1016/S0735-1097(02)01685-6

[8] Boulay, F., Berthier, F., Sisteron, O., Gendreike, Y. and Gibelin, P. (1999) Seasonal Variation in Chronic Heart Failure Hospitalizations and Mortality in France. Circulation, 100, 280-286. http://dx.doi.org/10.1161/01.CIR.100.3.280

[9] Sandoval, C., Walter, S., Krueger, P., Smieja, M., Smith, A., Yusuf, S. and Loeb, M. (2007) Risk of Hospitalization 
during Influenza Season among a Cohort of Patients with Congestive Heart Failure. Epidemiology and Infection, 135, 574-582. http://dx.doi.org/10.1017/S095026880600714X

[10] Gheorghiade, M., Vaduganathan, M., Fonarow, G. and Bonow, R. (2008) Rehospitalization for Heart Failure: Problems and Perspectives. Factors Identified as Precipitating Hospital Admissions for Heart Failure and Clinical Outcomes Findings from OPTIMIZE-HF. Archives of Internal Medicine, 168, 847-854. http://dx.doi.org/10.1001/archinte.168.8.847

[11] Go, A.S., Mozaffarian, D., Roger, V.L., Benjamin, E.J., Berry, J.D., Blaha, M.J., Dai, S., Ford, E.S., Fox, C.S., Franco, S., Fullerton, H.J., Gillespie, C., Hailpern, S.M., Heit, J.A. and Howard, V.J. (2014) AHA Statistical Update: Heart Disease and Stroke Statistics-2014 Update: A Report from the American Heart Association. Circulation, 129, e28e292. http://dx.doi.org/10.1161/01.cir.0000441139.02102.80

[12] Kannel, W.B. (2000) Incidence and Epidemiology of Heart Failure. Heart Failure Reviews, 5, 167-173. http://dx.doi.org/10.1023/A:1009884820941

[13] Jessup, M., Abraham, W.T., Casey, D.E., Feldman, A.M., Francis, G.S., Ganiats, T.G., Konstam, M.A., Mancini, D.M., Rahko, P.S., Silver, M.A., Stevenson, L.W. and Yancy, C.W. (2009) 2009-Focused Update: ACCF/AHA Guidelines for the Diagnosis and Management of Heart Failure in Adults: A Report of the American College of Cardiology Foundation/American Heart Association Task Force on Practice Guidelines Developed in Collaboration With the Inter- national Society for Heart and Lung Transplantation. Journal of the American College of Cardiology, 53, 1343-1382. http://dx.doi.org/10.1016/j.jacc.2008.11.009

[14] Centers for Disease Control and Prevention. CDC Protocol of Real Time RT-PCR for Influenza A (H1N1). http://www.who.int/csr/resources/publications/swineflu/CDCRealtimeRTPCR_SwineH1Assay-2009_20090430.pdf

[15] Informe técnico de influenza e vigilância de síndrome respiratória aguda grave (SRAG), de síndrome gripal (SG) e de internações por CID J09 a 118. Ministério da saúde. Secretaria de vigilância em saúde. http://portal.saude.gov.br/portal/arquivo/pdf/boletim eletronico influenza 25 03.pdf

[16] Melchior, T., Perosa, A., Camargo, C., Granato, C. and Bellei, N. (2015) Influenza Vírus Prevalence in Asymptomatic and Symptomatic Subjects during Pandemic and Postpandemic Periods. American Journal of Infection Control, 43, 460-464. http://dx.doi.org/10.1016/j.ajic.2015.01.032

[17] Bellei, N., Carraro, E., Perosa, A. and Granato, C. (2007) Patterns of Influenza Infections among Different Risk Groups in Brazil. Brazilian Journal of Infectious Diseases, 11, 399-402.

[18] Davis, M.M., Taubert, K., Benin, A.L., Brown, D.W., Mensah, G.A., Baddour, L.M., Dunbar, S. and Krumholz, H.M. (2006) Influenza Vaccination as Secondary Prevention for Cardiovascular Disease. Circulation, 114, 1549-1553. http://dx.doi.org/10.1161/CIRCULATIONAHA.106.178242

[19] Gurfinkel, E., Fuente, R., Mendiz, O. and Mautner, B. (2004) Flu Vaccination in Acute Coronary Syndromes and Planned Percutaneous Coronary Interventions (FLUVACS) Study. European Heart Journal, 25, 25-31. http://dx.doi.org/10.1016/j.ehj.2003.10.018

[20] Singleton, J.A., Wortley, P. and Lu, P.J. (2004) Influenza Vaccination of Persons with Cardiovascular Disease in the United States. Texas Heart Institute Journal, 31, 22-27.

[21] Bocchi, E.A., Braga, F.G., Ferreira, S.M., Rohde, L.E., Oliveira, W.A., Almeida, D.R., Moreira, M.C., Bestetti, R.B., Bordignon, S., Azevedo, C., Tinoco, E.M., Rocha, R.M., Issa, V.S., Ferraz, A. and Cruz, F. (2009) Sociedade Brasileira de Cardiologia. III Diretriz Brasileira de Insuficiência Cardíaca Crônica. Arquivos Brasileiros de Cardiologia, 93, 1-71.

[22] Bautista, E., Chotpitayasunondh, T., Gao, Z., Harper, S.A., Shaw, M., Uyeki, T.M., Zaki, S.R., Hayden, F.G., Hui, D.S., Kettner, J.D., Kumar, A., Lim, M., Shindo, N., Penn, C. and Nicholson, K.G. (2010) Clinical Aspects of Pandemic 2009 Influenza A (H1N1) Virus Infection. New England Journal of Medicine, 362, 1708-1719. http://dx.doi.org/10.1056/NEJMra1000449

[23] Kumar, A., Zarychanski, R., Pinto, R., Cook, D.J., Marshall, J., Lacroix, J., Stelfox, T., Bagshaw, S., Choong, K., Lamontagne, F., Turgeon, A.F., Lapinsky, S., Ahern, S.P., Smith, O. and Siddiqui, F. (2009) Critically Ill Patients with 2009 Influenza A (H1N1) Infections in Canada. JAMA, 302, 1872-1879. http://dx.doi.org/10.1001/jama.2009.1496

[24] Jain, S., Kamimoto, L., Bramley, A.M., Schmitz, A.M., Benoit, S.R., Louie, J., Sugerman, D.E., Druckenmiller, J.K., Ritger, K.A., Chugh, R., Jasuja, S., Deutscher, M., Chen, S., Walker, J.D. and Duchin, J.S. (2009) Hospitalized Patients with 2009 H1N1 Influenza in the United States, April-June 2009. New England Journal of Medicine, 361, 1935-1944. http://dx.doi.org/10.1056/NEJMoa0906695

[25] Centers for Disease Control and Prevention (2009) Hospitalized Patients with Novel Influenza A (H1N1) Virus Infection: California, April-May, 2009. Morbidity and Mortality Weekly Report, 58, 536-541.

[26] Kaiser, L., Wat, C., Mills, T., Mahoney, P., Ward, P. and Hayden, F. (2003) Impact of Oseltamivir Treatment on Influenza-Related Lower Respiratory Tract Complications and Hospitalizations. Archives of Internal Medicine, 163, 1667-1672. http://dx.doi.org/10.1001/archinte.163.14.1667 